\title{
MARRIAGE IN THE PRE-ISLAMIC ARAB WORLD
}

\author{
Dr Aurang Zeb Azmi* \\ DOI: 10.29370/siarj/issue2ar12 \\ Link: https://doi.org/10.29370/siarj/issue2ar12
}

\begin{abstract}
:
The Arabs, before the advent of Islam, had contacts with different nations and followers of various religions \& schools of thoughts. It influenced them in a number of different ways. Such impacts can easily be seen on their personal and social lives as we can see from their writings, poems and also from the Islamic literature including the Qur'ān and the Hadith. Marriage is an integral part of the social life and comes with many benefits e.g. continuation of the human generations, a mechanism for fulfilling our bodily needs while remaining pious and staying away from the evil. The pre-Islamic Arabs generally preferred marriage over remaining single except a few who were influenced with the Christianity. When Islam came it strengthened this view of getting married. The likening of marriages among Arabs was due to a number of factors. One of influencing factors was their bad habit of being inclined towards wars and their daily businesses, like feeding the animals. For wars, they needed the manpower. Similarly for grazing the animals, they needed youngsters to take up the task. They used to do 'arranged' as well as 'love marriages'. Some of them even practiced homosexuality. The current paper presents their view of marriage, its reasons, criteria, different ways \& kinds, right of divorce and duties of the couple.
\end{abstract}

KEYWORDS: Marriage, Pre-Islamic, Arab, Al-Shighār, Al-Mut‘ah

\section{Introduction:}

Marriage, its concepts, its benefits, its reasons and its ways are different and sometimes contrary in different societies and nations. Similarly,

\footnotetext{
* Assistant Professor Department Arabic, Faculty of Humanities and Languages, Jamia Millia Email: azebazmi@gmail.com
} 
divorce, its rights and its ways are different as per the opinions and thoughts of the peoples. The Arabs were a nation that had its own ways and thoughts in dealing with any problem, event and occurrence. Moreover they had contacts with the non-Arabs which paved way for infiltration of some foreign ideas and thoughts which were not purely Arabian. Marriage, which is an integral part of the society, also captured their attention and which is why we find them practicing several, and sometimes contrary, ways of marriage, divorce, and maternal or paternal duties.

The Arabian Concept of Marriage: The Arabs never liked to be bachelor except in a few cases. That is why they called those who didn't like to live with their couple as "Al-'Innīn" (العنين) for male and "Al'Inninah" (العنينة) for female and those who didn't like to talk with the women were named as "Al- 'Uzāt" (العزاة). They also coined a word "Zair al-Nisā" (زير النساء) which means "Ladies' man" for those who were fond of talking to women (without any bad will). There is a significant body of literature to suggest that they used to prefer to get married and to have many sons. They used to said: "النكاحُ خير" من الأيمة" (Tr.: Marriage is better than being single.)

Another famous concept among them was: “الزوجُ الصالحُ أبّ بعد أب”. (Tr.: The pious husband is like a father after the latter's death.)

Reasons behind their Marriages: There were several reasons behind their act of marriage and the most famous among them are (1) Need for man-power to fight against their enemies. (2) Eloquence in competition at the time of pride (boosting about their offsprings). (3) Continuity of their generation. (4) Personal services.

As far as the first reason is concerned they liked to marry with a girl that could give birth to many children as evident from their description of an ideal girl for marriage:

$$
\text { "-------" }
$$

Tr.: ----- that has a male baby in her womb, carries a male child on her hip and is followed by a boy.

Being proud of the great number of his men, Ḥājib b. Zurārah al-Taimī 
once said in a meeting of pride: “---- عديدًا لأنّا أكثرُ الناس ع.---.". (Tr.: Verily, we are greater than the people in number.)

Nufail bin 'Abd al-'Uzzá said to Harb bin Umayyah:

$$
\text { "يا أبا عمرو: أتنافر رجلاً هو أطول منك قامة-----وأكثر منك ولداً---"5 }
$$

(Tr. : O Abū 'Amr: Do you compete the person who is taller than you ---and more than you in the number of children ----).

Having more children was not only a desire for men but women also used to prefer it. It is known that one a beautiful, charming and wise Arab girl was offered marriage proposal from seven brothers. She advised her father to prefer the brother that was more handsome and that who could father many children. She is reported to have said:

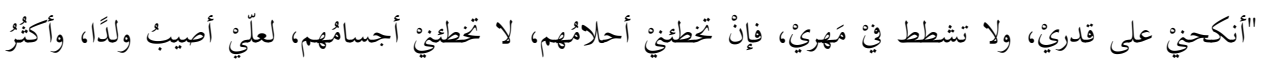

(Tr.: Marry me as per my ability and don't overrate my nuptial gift. If their minds could not reach me, their bodies will be able to find. It's because I could get children and be more in number.)

For this very feeling Allah points out the pride of a rich person to his poor fellow:

$$
\text { "------مكان له ثُرُ فقال لصاحبه وهو يحاورُه أنا أكثرُ منك مالًا وأعزّز نفرًا" ". }
$$

(Tr.: And he had fruit in abundance. So he told his companion, arguing boastfully with him, "I am richer than you in wealth and stronger in respect of men.)

It is clear that the increase in numbers helps a man to impress his opponent. 'Āmir bin al-Ṭarb al-'Adwānī said to his men:

$$
\text { "----إنّ عليك كما أنّ لك، وللكثرة الرعب، وللصبر الغلبة"8. }
$$

(Tr.: There will be a day against you as it is in favour of you, and the majority has its guts, and patience brings to you victory.)

As regards to the competition and pride in having male off-springs, Allah swt indicates about the love of the Arabs for the birth of a male child 
rather than a female child:

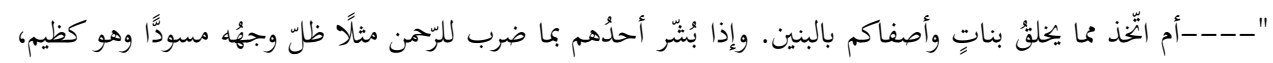

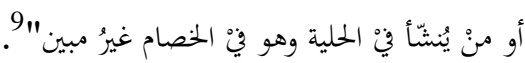

(Tr.: Has He taken daughters from what He has created, and honored you with sons. Yet when tidings are given to one of them of what that the like of which he ascribes to the Gracious God, his faces becomes darkened and he is choked with grief. Do you ascribe to God one who is reared among ornaments, and who is not clear in disputation.)

As for the continuity of the generation, the Arabs used to say:

“" من لا يلد لا وُلده". (Tr.: One who does not beget has not been born yet.)

And they also used to say:

$$
\text { "سوداء ولود خير من حسناء عاقر"11". }
$$

(Tr.: A black girl that gives birth to many children is better than a childless beautiful girl.)

The sons also used to the personal duties of their fathers like feeding the animal and helping their mother at home.

Criteria for Marriage: The first and the main criterion of the marriage among them was the origin of the bride/bridegroom and their blood relation. They did not like to marry with those whose blood relation was not considered 'pure' (according to their standards) or those who were not equal to them in the family status. For this very reason, they buried their daughters alive lest they would be married with those who were less than them in this regard. But when Islam came in, it abolished these false societal values and brought in piety and God fearing as the only status of superiority. Islam considered all human beings to be the children of Adam and accordingly equal in their status as human beings.

In addition to this, some of the other features of the types of wives the Arabs loved were being rich, healthy, well-built, beautiful, good-looking, bright like moon light, sharp-minded, sweet-voiced with pleasing conversations, talkative, having attractive and humble eyes, smooth cheeks, sweet lips, beautiful and tall neck, big breasts, childish palms, 
healthy hips, brown-skinned, thankful, co-operative, patient and able to bear many children. ${ }^{12}$

As for the bridegroom they preferred that who had following qualities:

Glorious, dreadful, defensive, determined, generous, helpful, mediator, wise, gentle, host, handsome, tall, peerless and envied. ${ }^{13}$

\section{Ways of Marriage among the Arabs}

The Arabs had several ways of marrying with the girls, which are as follows:

1. Al-Nikāh (النكاح) The Proper Way of Marriage): This type of marriage was very common in their societies. This was known as arranged marriage. In this way, the responsible persons of the bridegroom or the groom himself or the mediator used to ask the hand of the bride from her father or the responsible person and when upon the acceptance, family members from both sides used to gather to fix the dowry (مهر) and the date. On the fixed day, all of them used to gather in the presence of the just witnesses and took a little meat. Then they sat a tent for meeting of the couple. After this meeting, sweets used to be distributed.

The dowry was not used to be something Small back in the day and it used to be given by the bridegroom. The father of the bride used to be greeted with such greetings:

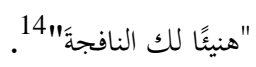

(Tr. Congratulations to you for the girl that can make an increase in your money.)

This dowry was paid in two installments; one before marriage and the other at the time of divorce or death of husband.

2. Al-Shighār (الثغار Vacancy): For fleeing from the huge dowries, the party exchanged marriage; the sister of a brother married the sister of the other and vice-versa. It could be in the case of daughters too. But Islam prohibited such type of marriage.

3. Al-Badal (البذل Alternative): This type of marriage is like Al-Shighār. 
4. Al-Khidn (الخدن Friend): In this way, girls and boys had a friendship and perhaps they were allowed to do almost everything. Allah swt pointed out about such relations:

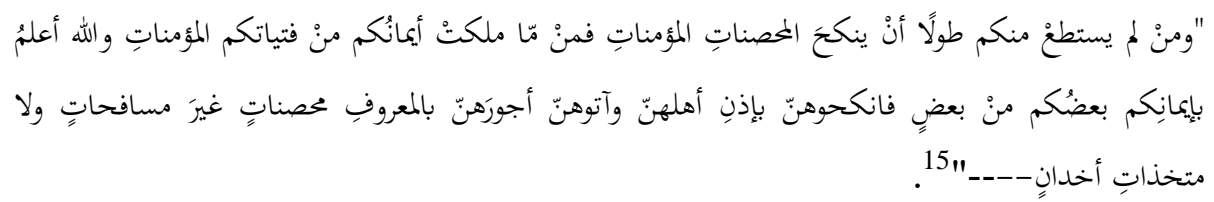

(Tr.: And whoever among you cannot [find] the means to marry free, believing women, then [he may marry] from those whom your right hands possess of believing slave girls. And Allah is most knowing about your faith. You [believers] are of one another. So marry them with the permission of their people and give them their due compensation according to what is acceptable. [They should be] chaste, neither [of] those who commit unlawful intercourse randomly nor those who take [secret] lovers. ---)

As for taking a girlfriend, its evidence has been given in the marriage of Al-Sifāh.

5. Al-Mut'ah (المتعةContract Marriage): In this way two persons could marry each other for a limited time. This type of marriage was permitted up to the early period of Islam but later it was prohibited for the fear of the spread of prostitution.

6. Al-Sifâh (السفاح/Fornication): In this way, two persons (male and female) used to do intercourse with each other and if they liked each other they could get married. But when Islam came in, it strongly prohibited such marriage. Allah swt says:

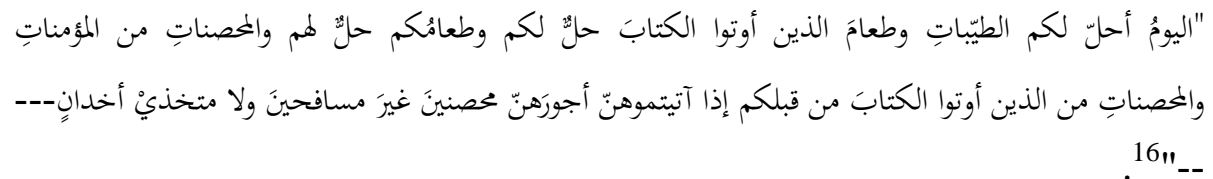

(Tr.: This day all good things have been made lawful for you. And the food of the People of the Book is lawful for you, and your food is lawful for them. And lawful for you are chaste believing woman and chaste woman from among those who were given the Book before you, when you give them their dowries, contracting valid marriage and not 
committing fornication nor taking secret paramours---.)

7. Al-Baghāya (البغايا Prostitution): This was a shameless way in which, a group of men would do an intercourse with a prostitute one after the other and when she used to get pregnant and gave birth to a child, she would link the baby to the man to whom the baby was more similar.

8. Al-Liwātah (اللواطة Homosexual): Like today, this type of sex was also found in the pre-Islamic period. Today it has become a legal marriage in some countries. But Islam has prohibited it. Narrating the story of the people of the Prophet Lūt, Allah says:

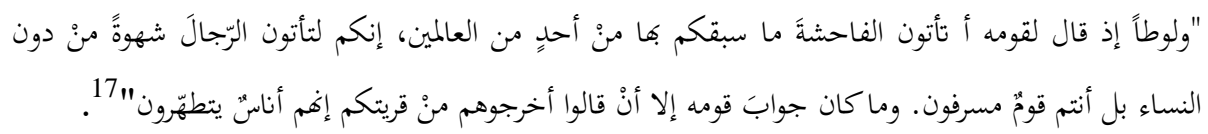

(Tr.: And We sent Lut----when he said to his people, 'Do you commit an abomination such as no one in the world ever did before you? You approach men with lust instead of women. Nay, you are a people who exceed all bounds. And the answer of his people was no other than that they said, 'Turn them out of your town, for they are men who would keep pure.)

9. Al-Sihāq (لاقحاقLesbianism): This type of sex was also existing in the pre-Islamic society but no such case was heard in the early period of Islam. Today it has become quite common and even lawful in some countries. Islam does not allow such type of sex.

10. Al-Istibdāa (الاستبضاع Trade): In this way, the husband used to say to his wife after menstruation to go to anyone whom he would point out and told her to do the intercourse with him. He would leave her till the next menstruation. If she would got pregnant then he (the husband) had the right to take her back or to send her back to the said person.

11. Al-Jam'a (الجمع Group): In this way of marriage, a group of men consisting of less than ten used to gather with a prostitute and do intercourse with her and made her pregnant. After the birth of child she would call them and none had courage to reject her call. Then she would relate her story and elabote what happened with her and link the baby to whom she liked. 
12. Al-Maqt (لمقتHate): This is another shameless type of marriage in which after the death of father, one of the sons, usually the eldest one, could marry his mother. This way for marriage considered to provide a shawl and shelter on her head.

13. Al-Jama‘ bain al-Ukhtain (النكاح بين الأختين Marriage with two Real Sisters): It was also narrated that some of them married with two real sisters in a time. But Islam has cancelled this type of marriage.

14. Al-Nikāh min al-Bint (لنكاح من البنتMarriage with one's own daughter): Being influenced with the Mazdaism which allows the marriage of a father with his own daughter some Arabs married with their own daughters. This type of marriage was prohibited by Islam.

15. Al-Tabattul (التبتّل): Being influenced by Christianity, some pre-Islamic Arabs (male and female both) preferred not to marry and to be bachelor forever. The men who did so were called "Al-Sarūr" (الصرور) and the women who did so were called "Al-Șarürah" (الصرورة) or "AlBatūll" (البنول). But Islam prohibited all type of monasticism. The Prophet Muhammad (PBUH) said: “" 18 (Tr.: There is no monasticism in Islam.)

He also said: “"19 (Tr.: Monasticism is not imposed upon us.)

He again said: "20 (Tr.: There is no monasticism in Islam.)

Apart from these types of marriages they also believed in the polygamy and used to marry up to ten women ${ }^{21}$. This was not only the case for men but woman could also marry with more than one husband at a time. $^{22}$ The famous poet Imru-ul-Qais married many times. ${ }^{23}$

16. Al-Bu'ülah (البعولة): There was another system of marriage in the preIslamic Arab world which was called "al-Ba'ūlah" but there are no details available regarding this in the history books in the pre-Islamic period.

Right and Way of Divorce: Both the partners used to have the right to divorce but mostly it was the husband who used to give divorce to the wife. The way of divorce among them was to change the direction of their 
door; from north to south or from east to west.

Rights and Duties of the Couple: The couple who married and then had issues had some rights. Also they had to fulfil some duties which are as follows:

\section{A. Rights of the Couple:}

- Rights of the Husband: In the pre-Islamic Arab world wife and children were considered as properties of the husband. So he had the right to sell them or to enforce them to commit any unlawful thing or to follow any course. We find many examples where fathers killed their issues, mortgaged their sons or lost their wives in gambling.

- Rights of the Wife: A wife had no rights in pre-Islamic period except that she was all in all in the home-related matters and it's because mostly the husband lived out of the house for hunting or fighting.

\section{B. Duties of the Couple:}

The duties of a husband were very limited. He only had to save the children and wife from the enemies. As for the wife, she had to do many jobs which are summarized in the words of the famous historian Tal'at Harb:

"أما أخلاقهنّ فهي بالجملة حسنة وخير ما يزينهنّ عزة النفس وشدة التعلق بالأهل والأزواج وقيامهنّ مقامَهم فِّ أكثر الأعمال ولا

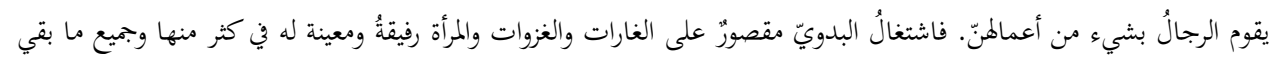

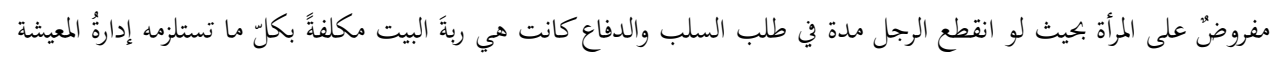

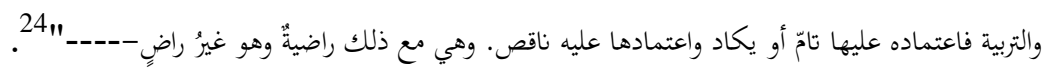

Tr.: As for their manners they had good manners. The best among them were ego, strong relations with their families and husbands and being their deputies in most of the jobs. But the men did not do any of their jobs. It's because the Bedouin was busy in capturing pastures and waging war. The woman had to help him even in most of this business. The remaining jobs were left to her as if the man became far from his house for a period of time in snatching or defense she was the master of the house and did all jobs including management of provision and upbringing of the children. So the husband was probably fully dependent upon her while she wasn't. After all of this, she was still happy with him but he wasn't.

Conclusion: It is seen from the above short discussion that the Arabs liked 
being married and they did not prefer to be single. The type of marriages they used to do ranged from the pure form of marriage where a husband lawfully marries her wife to the absolutely taboo where all forms of filth and evil were given a free hand to prevail. One of the key motives for them to marry was to have many children for to meet their needs (e.g. fighting and feeding). There were very rare cases of monasticism but majority did not like to be single.

\section{REFERENCES}

${ }^{1}$ Aḥmad Zakī Șafwat: Jamharatu Khuțub al-'Arab fì 'Uşūr al-'Arabiyyah al-Zāhirah, alMaktabah al-'Arabiyyah, Beirut, n.d, 1/20

${ }^{2}$ Ibid, $1 / 20$

${ }^{3}$ Ibid, $1 / 70$

${ }^{4}$ Ibid, $1 / 48$

${ }^{5}$ Ibid, $1 / 101$

${ }^{6}$ Ibid, $1 / 103$

${ }^{7}$ Sūrah al-Kahf: 34

${ }^{8}$ Jamharah Khuțub al-'Arab fi 'Ușūr al-'Arabiyyah al-Zāhirah, 1/124

${ }^{9}$ Sūrah al-Zukhruf: $18-20$

10 Allāmah Jawwād 'Alī: al-Mufașșal fi Tārīkh al-'Arab qabla al-Islām, Baghdād, 1968$69,4 / 634$

${ }^{11}$ Ibid, 4/634

${ }^{12}$ For details see: Jamharah Khuțub al-'Arab fi 'Ușūr al-'Arabiyyah al-Zāhirah, 1/21-22 and 68-70

${ }^{13}$ For details see: Jamharah Khuțub al-'Arab fi 'Ușūr al-'Arabiyyah al-Zāhirah, 1/22 and 70

14 Țal'at Harb: Tārīkh Dual al-'Arab wa al-Islām, Maktabah al-Iṣlāḥ, Sarā'imīr, A'ẓamgarh, 1989, 1/64

${ }^{15}$ Sūrah al-Nisā' $: 25$

${ }^{16}$ Sūrah al-Mā'idah: 5

${ }^{17}$ Sūrah al-A'rāf: 80-82

${ }^{18}$ Ahmad bin Hanbal, Musnad Ahmad bin Hanbal, n. d., 3/82

${ }^{19}$ Al-Tabrani, al-Mu'jam al-Kabir, No. of Hadith: 8236

${ }^{20}$ Ibn al-Mulaqqin, al-Badr al-Munir, Dar a-Hijrah, n.d, 7/427-429

${ }^{21}$ Tārīkh Dual al-'Arab wa al-Islām, 1/62-64

${ }^{22}$ Al-Mufașșal fi Tārīkh al-'Arab qabl al-Islām, 4/635

${ }^{23}$ Tārīkh Dual al-'Arab wa al-Islām, 1/189

${ }^{24}$ Tārīkh Dual al-'Arab wa al-Islām, 1/55

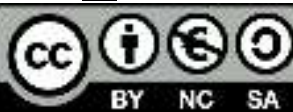

This work is licensed under a Creative Commons Attribution-NonCommercial-ShareAlike 4.0 International (CC BY-NC-SA 4.0) 